\section{US clinical trials imminent}

\section{Washington}

THE way is now being cleared for the first human gene therapy experiments, which could take place as early as next spring.

One research group, headed by Dr Ted Friedmann of the University of California at San Diego, has already received permission from the local Institutional Review Board (IRB) - the panel charged with protecting human research subjects - for clinical trials of a procedure aimed at correcting the genetic defect responsible for Lesch-Nyhan disease, although the proposal would still have to be approved by the National Institutes of Health Recombinant DNA Advisory Committee (RAC) before trials could begin.

In anticipation of Friedmann's and other proposals, RAC earlier this year established a working group on human gene therapy which is in the process of drawing up guidelines that will tell researchers what information to submit with their proposals. The working group, which includes ethicists as well as physicians and researchers, will also screen all such proposals before presenting them to the full RAC for consideration.

A draft of the guidelines, known as Points to consider in the design and submission of human gene therapy protocols, makes it clear that RAC plans to look beyond the questions of risk and protection of human subjects in its scrutiny of proposals. Many members of the working group strongly favour expanding RAC's purview to include such social issues as whether the procedures will be subject to proprietary rights and whether the proposed somatic-cell treatment could affect the reproductive cells of the patient.

Nevertheless, it is considered unlikely that the working group or the full RAC will turn down legitimate proposals from researchers seeking to perform somatic-cell gene therapy. One scientific member of the working group has in fact resigned in impatience at needless hand-wringing over a foregone conclusion.

Meanwhile, a broad consensus appears to have emerged among religious leaders and ethicists that although germ-cell therapy - that is, alteration of heritable traits - raises difficult ethical problems, no such objections exist in the case of somatic-cell therapy. The Office of Technology Assessment (OTA), which is releasing a study on human gene therapy next month, found strong support for this view among a group of theologians, religious leaders and ethicists it assembled for a meeting in September.

The Food and Drug Administration (FDA) is also preparing itself for the first gene therapy experiments. In an announcement to be published shortly in the Federal Register (and which will be part of a larger statement of overall federal policy on the regulation of biotechnology being coordinated by the Office of Science and Technology Policy), FDA will make clear that it intends to view recombinant DNA used for human gene therapy to be "biologicals" subject to FDA regulation.

Before beginning clinical trials, researchers would have to apply to FDA for an "investigational new drug" permit for the recombinant DNA; and FDA would have to approve the product's safety and effectiveness before its general use could begin. (Unlike the RAC guidelines, which are technically binding only upon research institutions that receive federal funds for recombinant DNA research, the FDA procedures have the force of law.)

The OTA report notes four research groups that are close to clinical trials. According to NIH officials, at least one grant application recently received by the genetics study section includes a proposal for human trials. All three of the target diseases mentioned in the OTA report as likely early candidates involve single gene defects that result in enzyme deficiencies.

One candidate is Lesch-Nyhan disease, recognized by renal failure and central nervous system disorders. The others are purine nucleoside phosphorylase deficiency and adenosine deaminase deficiency, both recognizable by the severe immunodeficiency they cause. Stuart Orkin (Harvard University) and David Martin (University of California, San Francisco, in collaboration with Genentech) have set their sights on genetic replacement of the deficient enzymes.

In each case, the defect is in the bone marrow; the most likely clinical approach would be to remove the patient's marrow, infect the cells with "repair" DNA carried by a retro-virus, and then replace the marrow.

\title{
Japanese telecommunications
}

\section{Future goes up in flames}

\section{Tokyo}

A LITTLE forgetfulness on the part of a Tokyo telephone repair man last week almost certainly caused Japan's first "telecommunications disaster" - and a heated debate about the vulnerability of the new "electronic society" into which the nation is rushing headlong.

What the repair man apparently forgot to do was to remove a small piece of rag wrapped around telephone cables in a lead pipe he was soldering. The result was a fire that spread into underground ducting and destroyed 90,000 telephone, databank and telex links, cutting off telecommunications in one whole ward of Tokyo and bringing a large part of the nation's banking operations to a halt.

Worst hit was Mitsubishi Bank, the nation's fourth largest. The fire cut the vital link between its central mainframe computer, which holds details of 6 million customers' accounts and records 200,000 transactions a day, and the office that relays the data to its 217 branches. All Mitsubishi's banking operations throughout Japan immediately came to a complete halt. Three more of the nation's top five banks also lost links with central computers and had to stop transactions in and around Tokyo, and 48 post office branches close to the fire had to halt savings account operations.

Businesses in the area were thrown into confusion. One of the big security companies had to stop trading when its computer was cut off, a major parcel company lost access to the central computer that records the routing and delivery of the 600,000 packages it handles each day, hospitals lost access to medical records normally sent by facsimile, the major overseas news wire service lost contact with foreign offices, and hundreds of retail and wholesale businesses saw telex, credit card and telephone orders vanish and supermarkets unable to order fresh stock.

Residents of Settagaya ward, where the fire broke out, slipped back into the pretelephone era. All telephone lines were cut, including those for emergency services, so that people had to report crimes and fires to local stations on foot. To try to see things through, the telecommunications monopoly, NTT, brought in armies of couriers to relay messages between the central telephone office and local residents - four days after the fire, nearly 5,000 messages a day were being carried. A satellite link was provided from a mobile transmitter, a mobile exchange brought in and 800 public telephones set up in the street - some 30 minutes of queuing was, however, needed to make a call.

Frantic efforts by NTT to restore telecommunication services have continued, with 10,000 man-days of work in the week since the fire. Telephone lines should soon be fully restored, although it will be another couple of weeks before all the damage is repaired.

Meanwhile, businesses in the affected area are finding to their chagrin that provisions for compensation are hopelessly out of date. An appeal to NTT by 600 shop owners on the grounds that "telephone paralysis is a new kind of city disaster" is not likely to meet with a generous response. The public telecommunications law, adopted around 30 years ago, provides only that if a telephone service is stopped for more than five days, compensation will be provided at the same rate as the basic rental charge: that means that compensation would reach about $£ 20$ after a threeweek stoppage.
Alun Anderson 